\title{
Direct medical costs of newly diagnosed cases of chronic obstructive pulmonary disease in Lithuania
}

\author{
NAUJAI DIAGNOZUOTŲ LĖTINĖS OBSTRUKCINĖS PLAUČIŲ LIGOS ATVEJŲ \\ TIESIOGINIAI MEDICININIAI KAŠTAI LIETUVOJE
}

\begin{abstract}
KĘSTUTIS MALAKAUSKAS ${ }^{1, *}$, VILIUS FLORESKUL ${ }^{2}$, MINDAUGAS ŠTELEMĖKAS ${ }^{3}$, RUGILĖ IVANAUSKIENE ${ }^{4}$

${ }^{1}$ Department of Pulmonology, Faculty of Medicine, Medical Academy, Lithuanian University of Health Sciences, ${ }^{2}$ Department of Coordination of Preventive Programs, Hospital of Lithuanian University of Health Sciences Kauno klinikos, ${ }^{3}$ Health Research Institute, Faculty of Public Health, Medical Academy, Lithuanian University of Health Sciences, ${ }^{4}$ Department of Preventive Medicine, Faculty of Public Health, Medical Academy, Lithuanian University of Health Sciences
\end{abstract}

\begin{abstract}
Summary. Background. Chronic obstructive pulmonary disease (COPD) is an under-diagnosed, life-threatening lung disease, which is mainly caused by active smoking, and provokes significant financial burden for the health care sector. COPD is avoidable, therefore strong health policy decisions are crucial in prevention, and to support the policies the analysis of economic impact is an important component in order to illustrate the burden of disease to the society. Therefore, the aim of this study was to estimate annual direct medical costs of newly diagnosed COPD cases in Lithuania. Material and methods. A retrospective, bottom-up, incidence-based cost of illness study included all newly diagnosed COPD patients in Lithuania in 2015. Data was taken from the National Health Insurance Fund under the Ministry of Health (NHIF) database SVEIDRA, and included all cases coded as J44.0, J44.1, J44.8 or J44.9 (6870 cases in total). All costs were assessed from the perspective of health care and consisted of three broad categories: outpatient care related costs, hospital related inpatient care, and reimbursable prescription drugs. The estimated costs are given in 2015 prices and presented in Euros $(€)$. Results. Total direct medical costs of new COPD cases were estimated to be $€ 1,679,879$ in 2015 . Inpatient costs accounted for $€ 928,054$ or $55.2 \%$ of the total direct costs, pharmaceutical costs - $€ 633,429$ (37.7\%), and the outpatient services took $€ 118,396$ or $7.1 \%$ of the total. The average of total direct costs per-patient was $€ 244.5$, and the highest cost was for per-hospitalized patient $-€ 1,176.2$. Conclusions. Inpatient services and pharmaceutical costs were the key drivers of direct medical cost of new COPD cases in Lithuania in 2015 accounting
\end{abstract} for more than half and third of all expenses, respectively.

Keywords: healthcare, cost of illness, chronic obstructive pulmonary disease.

Santrauka. İvadas. Lètinè obstrukcinè plaučių liga (LOPL) yra nepakankamai diagnozuojama, nepagydoma liga, kurią dažniausiai sukelia aktyvus rūkymas, o tai lemia didelę finansinę naštą sveikatos priežiūros sistemai. LOPL galima išvengti, todèl svarbu priimti griežtus sveikatos politikos sprendimus profilaktikos srityje, remti ligos ekonominio poveikio tyrimus siekiant parodyti LOPL naštą visuomenei. Tyrimo tikslas. Šio tyrimo tikslas - įvertinti naujai diagnozuotų LOPL atvejų metinius tiesioginius medicininius kaštus Lietuvoje. Metodai. Tai retrospektyvusis $2015 \mathrm{~m}$. naujai diagnozuotų LOPL atvejų Lietuvoje tiesioginių medicininių kaštų tyrimas. Duomenys buvo gauti iš Nacionalinio sveikatos draudimo fondo prie Sveikatos apsaugos ministerijos duomenų bazès SVEIDRA ir apima visus atvejus, koduojamus kaip J44.0, J44.1, J44.8 arba J44.9 (iš viso 6870 atvejų). Visus kaštus sudarè trys kategorijos: ambulatorinės paslaugos, stacionarinès paslaugos ir kompensuojamų receptinių vaistų kaštai. Apskaičiuoti kaštai pateikiami eurais 2015 m. kainomis. Rezultatai. Apskaičiuota, kad iš viso tiesioginiai medicininiai kaštai, susiję su naujais LOPL atvejais, siekè 1679879 Eur. Stacionarinių paslaugų kaštai sudare 928054 Eur. arba 55,2 proc. visų tiesioginių kaštų, kompensuojami receptiniai vaistai - 633429 Eur (37,7 proc.), o ambulatorinių paslaugų kaštai - 118 396 (7,1 proc.). Vidutinès metinès išlaidos vienam naujai diagnozuotam LOPL atvejui buvo 244,5 Eur, o stacionarinių paslaugų išlaidos vienam dèl LOPL hospitalizuotam pacientui siekè 1176,2 Eur. Išvados. Stacionarinès paslaugos ir kompensuojamų receptinių vaistų kaštai buvo pagrindinès naujų LOPL atvejų tiesioginių medicininių kaštų priežastys Lietuvoje 2015 m., sudariusios, atitinkamai, daugiau kaip pusę ir trečdalị visų kaštų.

Reikšminiai žodžiai: sveikatos priežiūra, ligos kaštai, lètinè obstrukcinė plaučių liga.

${ }^{*}$ Corresponding author: Department of Pulmonology, Faculty of Medicine, Medical Academy, Lithuanian University of Health Sciences, Kaunas, Lithuania. A. Mickevičiaus g. 9, 44307, Kaunas, Lithuania. Electronic address: kestutis.malakauskas@lsmuni.lt; Tel.: +370 37326737 


\section{Moksliniai darbai ir apžvalgos}

\section{INTRODUCTION}

Chronic obstructive pulmonary disease (COPD) is a lung disease characterized by chronic obstruction of lung airflow that interferes with normal breathing and is not fully reversible. COPD is an under-diagnosed, life-threatening lung disease. It is a major public health problem, responsible for premature mortality and significant cost to health systems. According to the World Health Organization, it is expected that the burden of COPD will increase during the coming decades, mostly due to continued exposure to risk factors, population growth and aging, and is likely to become the third leading cause of death by 2030 [1]. The Global Burden of Disease Study 2015 estimated the global prevalence of COPD at about 174 million cases [2]. The high prevalence of COPD makes it one of the leading causes of morbidity and mortality worldwide - in 2015 COPD ranked third among the global death rates, with about 3.2 million patients dying of the disease [3].

Cost-of-illness studies are useful and might help to determine the costs of the diagnosis and treatment of specific illness and to broaden the understanding of public health problems [4]. The direct cost of illness studies, in terms of cost and consumption of resources, are important and usually include: medical prescriptions, consultations, visits to the emergency room and hospitalizations. In 2010, the economic burden of COPD in the United States was projected to be approximately US $\$ 49.9$ billion, while in Europe the cost of COPD was estimated to be $€ 48.4$ billion in 2011, of which $€ 23.3$ billion was referred to direct health care expenditures $[5,6]$.

To our knowledge, there are no studies, estimating the economic burden of COPD, performed in Baltic States. Thereby, that is essential for decisions makers regarding strategic planning, management, and allocation of resources relayed with the various components of COPD. The objective of the study was to estimate annual direct medical costs associated with new COPD cases in Lithuania.

\section{MATERIAL AND METHODS}

\section{Study design and sample}

A retrospective, bottom-up, incidence-based cost of illness study included all newly diagnosed COPD patients in Lithuania, during the period from 01/01/2015 to $31 / 12 / 2015$. The data was taken from the National Health Insurance Fund under the Ministry of Health (NHIF) database SVEIDRA, and included all cases coded as J44.0, J44.1, J44.8 or J44.9 (ICD-10-AM classification system), in total 6870 cases of COPD was included. The data on COPD prevalence was also taken from this database. In addition, patient level resource use and cost data ware acquired by matching individual patients from the incidence cohort to their resource use records, where COPD as defined above, was the main diagnosis.

The study was approved by the Lithuanian Bioethics Committee (No. BE-2-52, December 30, 2016).

\section{Recourse use and cost estimation}

Resource use data was used for estimation of direct costs, during the defined time period. All costs were assessed from the perspective of health care (NHIF, the third-party payer) and consisted of three broad categories.

Outpatient care related costs, which included costs of services provided by different health care levels (primary, secondary, tertiary) as well as the costs of all the

Table 1. Active substances included in reimbursed prescriptions

\begin{tabular}{|l|l|}
\hline \multicolumn{1}{|c|}{ ATC code } & \multicolumn{2}{|c|}{ Active substance } \\
\hline Selective $\boldsymbol{\beta}_{2}$-adrenoreceptor agonists \\
\hline R03AC02 & Salbutamol \\
\hline R03AC04 & Fenoterol \\
\hline R03AC12 & Salmeterol \\
\hline R03AC13 & Formoterol \\
\hline R03AC18 & Indacaterol \\
\hline
\end{tabular}

Adrenergics in combination with corticosteroids or other drugs, excl. anticholinergics

\begin{tabular}{|l|l|}
\hline R03AK06 & Salmeterol and fluticasone \\
\hline R03AK07 & Formoterol and budesonide \\
\hline R03AK08 & Formoterol and beclometasone \\
\hline R03AK10 & Vilanterol and fluticasone furoate \\
\hline
\end{tabular}

Adrenergics in combination with anticholinergics

\begin{tabular}{|l|l|}
\hline R03AL01 & Fenoterol and ipratropium bromide \\
\hline R03AL03 & Vilanterol and umeclidinium bromide \\
\hline R03AL04 & Indacaterol and glycopyrronium bromide \\
\hline R03AL05 & Formoterol and aclidinium bromide \\
\hline
\end{tabular}

\section{Glucocorticoids}

\begin{tabular}{|l|l|}
\hline R03BA02 & Budesonide \\
\hline R03BA05 & Fluticasone \\
\hline
\end{tabular}

\section{Anticholinergics}

\begin{tabular}{|l|l|}
\hline R03BB01 & Ipratropium bromide \\
\hline R03BB04 & Tiotropium bromide \\
\hline R03BB05 & Aclidinium bromide \\
\hline R03BB06 & Glycopyrronium bromide \\
\hline
\end{tabular}

ATC $=$ Anatomical Therapeutic Chemical (ATC) Classification System. 


\section{Moksliniai darbai ir apžvalgos}

diagnostic examinations conducted in these settings. Primary health care level presented family physicians' services, when secondary and tertiary levels - pulmonologists'. It was assumed that the expenses faced by NHIF are representative estimates of those costs.

The second category of costs was prescription of ambulatory drugs (at least one prescription for 1 month period and longer) reimbursed by NHIF. Specifically, NHIF covers $80 \%$ of the price of the generic pharmaceutical formulation for all inhaled drugs related with COPD. Active substances included in the reimbursed prescriptions and obtained from NHIF database are presented in Table 1. In Lithuania reimbursement of these drugs is based on their approved base price in that year, which includes all the expenses along the distribution chain, hence is suitable estimation of costs attributable to provision of these drugs.

Hospital related inpatient care was the third broad category of costs and included costs that occurred during hospitalization. Diagnostic Related Group (DRG) classification system was used to quantify inpatient care services individually for every hospitalized patient, hence cost estimation relied on national social insurance claims to reimburse the hospitalization cases where COPD was the main diagnosis. These costs included costs of physician consultations, diagnostic investigations, treatment and other medical procedures provided in the inpatient setting.

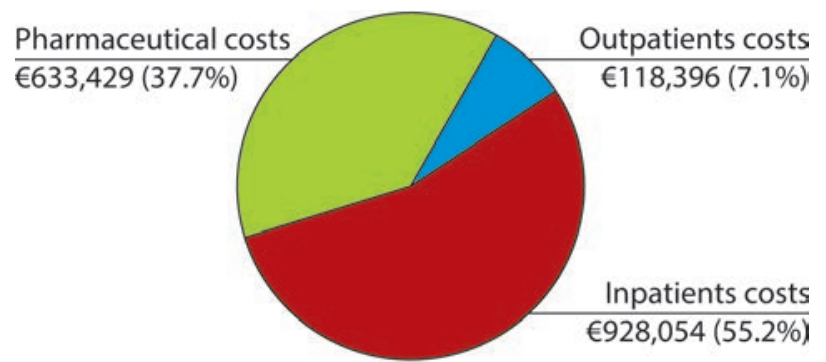

Figure 1. Direct medical costs for new COPD patients in Lithuania in 2015
Table 2. Outpatient costs for newly diagnosed COPD patients

\begin{tabular}{|l|c|c|c|c|}
\hline $\begin{array}{c}\text { Healthcare } \\
\text { services }\end{array}$ & $\begin{array}{c}\text { Patients } \\
(\mathbf{n})\end{array}$ & $\begin{array}{c}\text { Visits } \\
(\mathbf{n})\end{array}$ & $\begin{array}{c}\text { Cost } \\
(\boldsymbol{\epsilon})\end{array}$ & $\begin{array}{c}\text { Mean cost } \\
\text { per-patient }(\boldsymbol{\epsilon})\end{array}$ \\
\hline Primary & 4,910 & 14,161 & 6,228 & 1.3 \\
\hline Secondary & 4,646 & 8,884 & 100,467 & 21.6 \\
\hline Tertiary & 320 & 469 & 11,701 & 36.6 \\
\hline Total & 6,870 & 23,514 & 118,396 & 17.2 \\
\hline
\end{tabular}

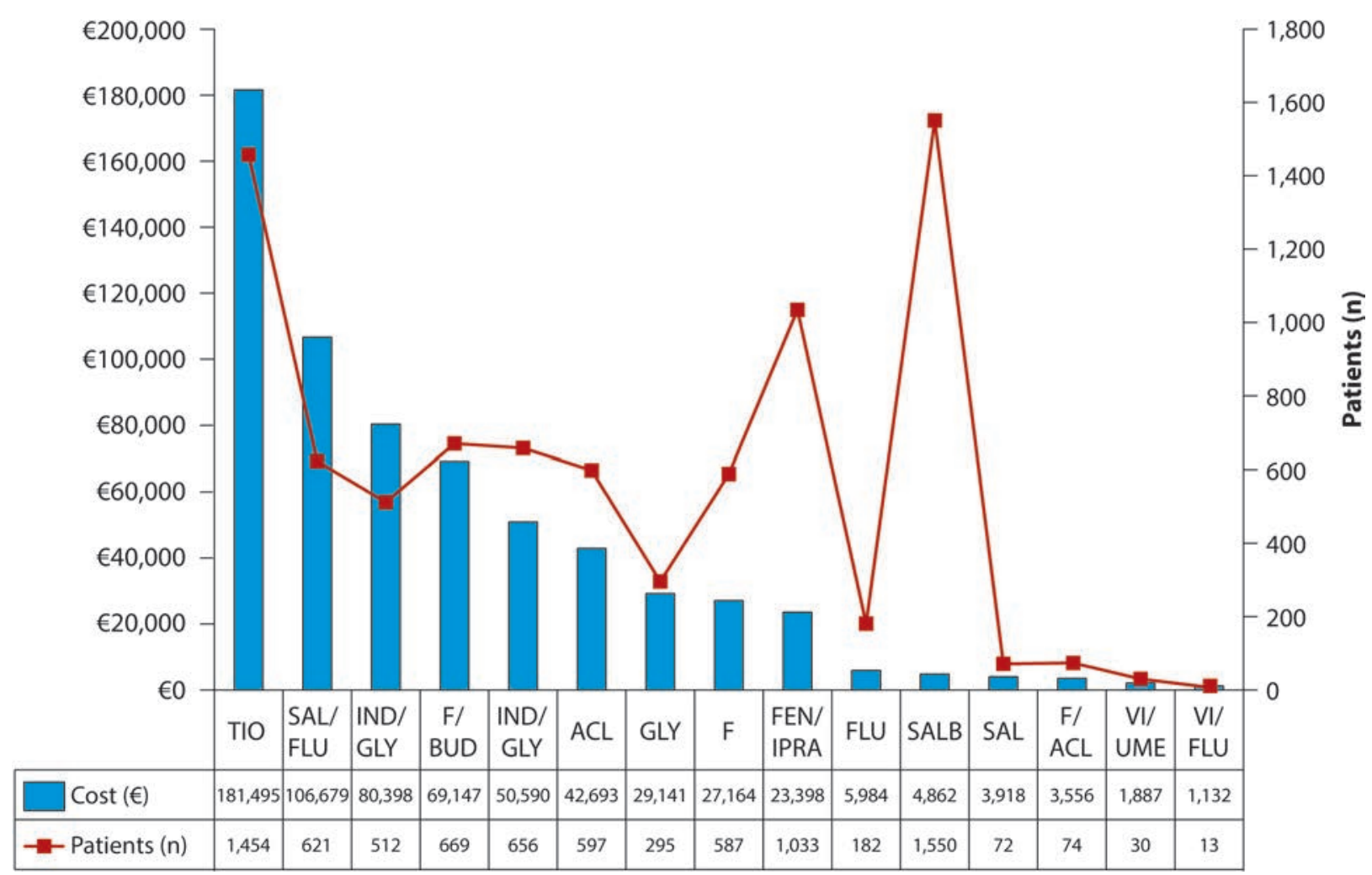

Figure 2. Costs of commonly used inhaled medicines for newly diagnosed COPD patients in 2015.

TIO - tiotropium; SAL - salmeterol; FLU - fluticasone; IND - indacaterol; GLY - glycopirronium; F - formoterol; BUD - budenoside; ACL - aclidinium; FEN fenoterol; IPRA - ipratropium; SALB - salbutamol; VI - vilanterol; UME - umeclidinium. 


\section{Moksliniai darbai ir apžvalgos}

\section{Data analysis and estimation of direct health care costs}

The COPD incidence and cost data were processed in MS Access database, where patient incidence and demographic data records were merged to the corresponding individual level cost data; checked for duplicates and filtered to assure that only records matching the previously defined inclusion criteria are included in the analysis. Data analysis was conducted in MS Excel where patient level data was summarized and tabulated. Annual average direct medical costs per one patient were calculated by dividing total costs by the number of new COPD patients. Average costs per patient in each category were estimated by dividing total costs in each category by the number of patients that received corresponding services. All costs are given in 2015 prices and presented in Euros $(€)$.

\section{RESULTS}

Data on direct medical costs was collected from a sample of 6870 newly diagnosed COPD cases in Lithuania in 2015: 4111 (59.8\%) were men and 2759 (40.2\%) - women. The new COPD cases accounted for $21.7 \%$ of all 31,644 COPD patients in that year. Total direct medical costs of new COPD cases were estimated to be $€ 1,679,879$. Major cost drivers were inpatient (55.2\%) and pharmaceutical costs (37.7\%) when the cost of outpatient services accounted for only $7.1 \%$ (Figure 1). Annual average direct medical costs per one newly diagnosed COPD patient reached $€ 244.5$.

\section{Outpatient costs}

Outpatient costs spent on different levels of healthcare services from January 1 to December 31, 2015 were estimated to be $€ 118,396$ (Table 2). The total number of ambulatory visits was 23,514 (3.4 visits per patient) and the average cost for one person per year was $€$ 17.2. The highest number of consultations was given by family physicians in the primary healthcare service. However, the main cost was spent in the secondary healthcare level $(€ 100,467)$, when the highest cost per-patient was in tertiary healthcare service $(€ 36.6)$.

\section{Pharmaceutical costs}

Pharmaceutical expenses were spent for inhaled medicines in ambulatory settings and estimated at $€ 633,429$. However, according to NHIF database, only 4398 patients (64.0\% of all new COPD cases) had received reimbursed medicines from pharmacies. Costs of commonly used inhaled medicines are presented in Figure 2. The largest part of expenses $(€ 181,495)$ was for tiotropium taking $28.7 \%$ costs of all reimbursed medicines. Although most often was prescribed salbutamol, the expenses for this drug took only $0.8 \%$ of all pharmaceutical expenses (€4862). The mean
Table 3. Hospitalization costs for newly diagnosed COPD patients

\begin{tabular}{|l|c|c|c|c|}
\hline $\begin{array}{l}\text { Indi- } \\
\text { cator }\end{array}$ & $\begin{array}{c}\text { Patients } \\
\text { (n) }\end{array}$ & $\begin{array}{c}\text { Hospita- } \\
\text { lizations } \\
(\mathbf{n})\end{array}$ & $\begin{array}{c}\text { Costs } \\
(\boldsymbol{\epsilon})\end{array}$ & $\begin{array}{c}\text { Mean cost } \\
\text { per-hospita- } \\
\text { lized patient } \\
(\boldsymbol{(})\end{array}$ \\
\hline \multicolumn{5}{|l|}{ The number of hospitalizations } \\
\hline 1 & 578 & 578 & 461,474 & 798.4 \\
\hline 2 & 123 & 246 & 189,168 & $1,538.0$ \\
\hline$\geq 3$ & 88 & 364 & 277,411 & $3,152.4$ \\
\hline COPD outcomes & 756 & 1,115 & 850,520 & $1,125.0$ \\
\hline Alive & 756 & 73 & 77,534 & $2,349.5$ \\
\hline Death & 33 & 1,188 & 928,054 & $1,176.2$ \\
\hline Total & 789 & &
\end{tabular}

reimbursable pharmaceutical cost per newly diagnosed COPD patient per year was $€ 92.2$.

\section{Inpatient costs}

The biggest proportion of NHIF expenditures was assigned to hospital related inpatient care. During 2015 , patients from this study population had a total of 1188 hospitalization episodes and involved 789 patients $-11.5 \%$ of all new COPD cases. The total cost of these hospitalization episodes amounted to €928,054 (Table 3). The inpatient hospital stays with the main diagnosis of COPD incurred the average annual cost per-hospitalized person of $€ 1,176.2$. This cost increased in relation to number of hospitalizations, being the highest in patients with 3 and more episodes. 33 patients ( $4.2 \%$ of all hospitalized new COPD patients) had lethal outcome due to COPD with twice higher inpatient care expenses compared to non-lethal outcome of disease.

\section{DISCUSSION}

To our knowledge this is the first study that aimed to capture a picture of direct costs of COPD patients in Lithuania and Baltic states. We made analysis of the annual direct medical costs of newly diagnosed cases of COPD in Lithuania in 2015. The structure of costs included expenses for outpatient and inpatient health services as well as pharmaceutical costs for inhaled maintenance medicines. A total number of 6,870 new COPD cases were estimated that accounted for $21.7 \%$ of all COPD patients in Lithuania in 2015. Total annual burden of new diagnosed COPD was estimated to be $€ 1,679,879$. Major cost drivers were inpatient and pharmaceutical costs $-55.2 \%$ and $37.7 \%$, respectively. The highest expenses were for inpatient services reaching $€ 1,176.2$ per-patient hospitalized due to COPD.

The estimated costs in current study were based on 


\section{Moksliniai darbai ir apžvalgos}

NHIF database including outpatient and inpatient medical services and inhaled maintenance medicines costs. There are several aspects of burden-of-disease that have not been taken into consideration in this study, and might have led to an underestimation of its true cost. Cost estimates did not include hospital outpatient services, emergency services, vaccination, rehabilitation, oxygen therapy at home, lung transplantation and other health care services that COPD patients could have received. In addition, COPD is recognized as a risk factor for multiple chronic conditions as cardiovascular diseases, pneumonia, depression, etc. Comorbidities contribute to higher direct costs in COPD patients with more frequent hospital admissions [7, 8]. However the analysis of the costs of comorbidities in COPD patients was not included in the current study.

It is difficult to compare direct cost of other countries due to variations which are mainly attributed to geographic differences, used measurement methods, national health care traditions [9]. Per-patient related direct costs for COPD have been found to vary widely, as US\$1,690 in Netherlands, US\$2,255 in Germany, US\$3,406 in France, US\$3570 in Spain, and up US\$9,981 in the USA (costs were converted to US dollars) [10]. Other studies showed that the direct costs per-patient were $€ 13,179$ in Sweden, €2,932 in Italy, €2,810 in Greece, €1,272 in Bulgaria [11-14]. We estimated much lower annual direct medical costs per one newly diagnosed COPD patient in Lithuania reaching at $€ 244.5$. It could be explained that, firstly, we studied only new COPD cases with possible milder disease course, secondly, healthcare services for these patients were provided for a shorter period than 12 months, depending on the time of diagnosing COPD.

Outpatient service costs for COPD accounted for only $7.1 \%$ of all direct medical costs taking only $€ 17.2$ per-patient in 2015. Secondary outpatient health service dominated in the structure of costs $-84.9 \%$ of all outpatient costs. It is not surprising as in Lithuania there is regulation that initial COPD diagnosis and management is provided by pulmonologists who are working mainly in the secondary healthcare service level. In Bulgaria, COPD expenses for general practitioners' services accounted $€ 10.7$ and for pulmonologists - €23.2 [14]. That approximately corresponds to costs of healthcare service levels in Lithuania where $€ 1.3$ was spend in primary level, €21.6 and $€ 36.6$ - in secondary and tertiary levels, respectively. Meanwhile, in Italy total outpatient costs were up to $€ 463$ [12].

It is known that direct and indirect costs are rising with increasing COPD severity $[8,15,16]$. Unfortunately, in NHIF database there was no data about the severity of COPD so it was impossible to compare costs by disease severity. We estimated costs of phar- maceutical medicines at $€ 633,429$ - 37.7\% of all direct medical costs. The annual average cost per-patient for medicines was only €92.2. These expenses were much lower compared with costs in other countries: $€ 732$ in Greece, €693 in Bulgaria, €499 in Italy [12, $14,17]$. Low pharmaceutical expenses in Lithuania could be caused, firstly, as only new COPD cases (and possible milder patients) we studied, secondly, poor patients' compliance - by NHIF database only $64 \%$ of all new COPD patients had received reimbursed medicines from pharmacies. The highest expenditure was due to prescriptions of long-acting anticholinergic tiotropium, followed by combination of long-acting $\beta_{2}$-agonist and corticosteroid in one device salmeterol/ fluticasone and amounted $45 \%$ costs of all inhaled medicines.

Previous studies have reported that the key drivers for higher direct cost of COPD include inpatient hospitalizations $[10,11,15]$. In our observation we found that inpatient costs were the highest and accounted in total $€ 928,054$ (55.2\% of all direct costs). Annual average cost per-hospitalized COPD patient reached up $€ 1,176.2$. By other literature, hospital related perpatient costs were $€ 1970$ in Italy, $€ 1,512$ in Greece, $€ 545$ in Bulgaria [12-14]. In our study we found that in comparison with the more beneficial outcomes (patient survival) the costs of lethal COPD cases generated twice as higher inpatient expenses $(€ 1,125.0$ $v s € 2,349.5)$. These high costs possible were related with longer stay in the hospital and management in intensive care units. Patients with frequent hospitalizations ( $\geq 3$ events) caused 4 fold higher expenses compared with patients who were hospitalized only once: $€ 3,152.4 v s € 798.4$. Thus, a reduction in exacerbations could lead to undisputable economic benefit.

There are only a few data about the costs of other diseases in Lithuania. Previously it was shown that total direct medical cost of new cases of breast cancer in Lithuania ( $\mathrm{n}=1142)$ was estimated at $€ 2,946,377$ in 2011 and accounted $€ 2,580$ per-patient [18]. Mean annual type 2 diabetes mellitus direct healthcare costs per patient reached to €956 [19].

As there are different approaches to estimate the costs of illness, the approach in this study was to focus on the costs of new cases of COPD as this approach might be more easily used in Lithuanian policy making processes in order to illustrate the impact of avoidable costs for the health care in a light of newly diagnosed cases that are diagnosed every year, and to advocate for a health policy to maintain the risk factors of COPD. The future direction of research in this area in Lithuania should be the estimation of all the COPD related cost-of-illness including indirect costs in order to create a big picture of the current burden of disease. 


\section{Moksliniai darbai ir apžvalgos}

\section{CONCLUSIONS}

The management of COPD in Lithuania is associated with intensive resource use and significant economic burden. Inpatient services and pharmaceutical costs are the key drivers of direct medical cost. The results of this study can contribute to rationalization policies in the field of health care which may significantly reduce the burden on healthcare system in Lithuania.

Conflicts of Interest: The authors declare no conflict of interest.

Gauta 20180811

Priimta 20180831

\section{REFERENCES}

1. Soriano JB, Abajobir AA, Abate KH, Abera SF, Agrawal A, Ahmed MB, et al. Global, regional, and national deaths, prevalence, disability-adjusted life years, and years lived with disability for chronic obstructive pulmonary disease and asthma, 1990-2015: a systematic analysis for the Global Burden of Disease Study 2015. Lancet Respir Med. 2017; 5(9):691-706.

2. Vos T, Allen C, Arora M, Barber RM, Bhutta ZA, Brown A, et al. Global, regional, and national incidence, prevalence, and years lived with disability for 310 diseases and injuries, 19902015: a systematic analysis for the Global Burden of Disease Study 2015. Lancet. 2016; 388(10053):1545-602.

3. Wang H, Naghavi M, Allen C, Barber RM, Bhutta ZA, Carter A, et al. Global, regional, and national life expectancy, all-cause mortality, and cause-specific mortality for 249 causes of death, 1980-2015: a systematic analysis for the Global Burden of Disease Study 2015. Lancet. 2016; 388(10053):1459-544.

4. Larg A, Moss JR. Cost-of-illness studies: a guide to critical evaluation. Pharmacoeconomics. 2011; 29(8):653-71.

5. Guarascio AJ, Ray SM, Finch CK, Self TH. The clinical and economic burden of chronic obstructive pulmonary disease in the USA. Clinicoecon Outcomes Res. 2013; 5:235-45.

6. Gibson GJ, Loddenkemper R, Sibille Y, Lundbäck B. European Lung White Book, Respiratory Health and Disease in Europe European Respiratory Society, 2013. Available from: http://www.erswhitebook.org/chapters/the-economic-burdenof-lung-disease (accessed on 17 May 2018).

7. Huber MB, Wacker ME, Vogelmeier CF, Leidl R. Excess costs of comorbidities in chronic obstructive pulmonary disease: a systematic review. PLoS One. 2015; 10(4):e0123292.

8. Wacker ME, Jörres RA, Schulz H, Heinrich J, Karrasch S, Karch A, et al. Direct and indirect costs of COPD and its comorbidities: Results from the German COSYCONET study. Respir Med. 2016; 111:39-46.

9. Ford E, Croft J, Mannino D, Wheaton A, Zhang X, Giles W. COPD surveillance - United States, 1999-2011. Chest. 2013; 144(1):284-305.

10. Foo J, Landis SH, Maskell J, Oh Y-M, van der Molen T, Han MK, et al. Continuing to Confront COPD International Patient Survey: Economic Impact of COPD in 12 Countries. PLoS One. 2016; 11(4):e0152618.

11. Lisspers $K$, Larsson $K$, Johansson G, Janson C, Costa-Scharplatz M, Gruenberger JB, et al. Economic burden of COPD in a Swedish cohort: the ARCTIC study. Int J Chron Obstruct Pulmon Dis. 2018; 13:275-85.

12. Dal Negro RW, Bonadiman $L$, Turco $P$, Tognella $S$, Iannazzo S. Costs of illness analysis in Italian patients with chronic obstructive pulmonary disease (COPD): an update. Clinicoecon Outcomes Res. 2015; 7:153-9.

13. Souliotis K, Kousoulakou H, Hillas G, Tzanakis N, Toumbis M, Vassilakopoulos T. The direct and indirect costs of managing chronic obstructive pulmonary disease in Greece. Int J Chron Obstruct Pulmon Dis. 2017; 12:1395-400.

14. Kamusheva $M$, Dimitrova M, van Boven JF, Postma MJ, van der Molen T, Kocks JW, et al. Clinical characteristics, treatment patterns, and socio-economic burden of COPD in Bulgaria. J Med Econ. 2017; 20(5):503-9.

15. Jansson SA, Backman $H$, Stenling A, Lindberg A, Ronmark E, Lundbäck B. Health economic costs of COPD in Sweden by disease severity - has it changed during a ten years period? Respir Med. 2013; 107(12):1931-8.

16. Stafyla E, Kerenidi T, Gerogianni I, Geitona M, Daniil Z, Gourgoulianis KI. The pharmacological cost of COPD during Greek economic crisis. Int J Chron Obstruct Pulmon Dis. 2017; 12:461-6.

17. Stafyla E, Geitona M, Kerenidi T, Economou A, Daniil Z, Gourgoulianis KI. The annual direct costs of stable COPD in Greece. Int J Chron Obstruct Pulmon Dis. 2018; 13:309-15.

18. Ivanauskienė $R$, Domeikienė $A$, Kregždytẻ R, Milašauskienė $\check{Z}$, Padaiga $\check{Z}$. The cost of newly diagnosed breast cancer in Lithuania, 2011. Medicina (Kaunas). 2015; 51(1):63-8.

19. Domeikiené A, Vaivadaitẻ J, Ivanauskienẻ R, Padaiga Ž. Direct cost of patients with type 2 diabetes mellitus healthcare and its complications in Lithuania. Medicina (Kaunas). 2014; 50(1):54-60. 